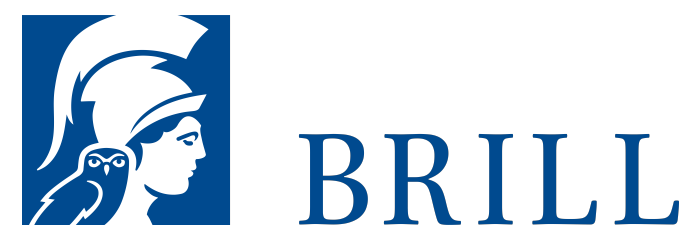

\title{
Die verkohlten Papyri aus Bubastos (P.Bub. III 6)
}

\section{Tafelband}

Author: Klaus Maresch

Die Nordrhein-Westfã und der KÃ $1 / 4 n s t e$ ist eine Vereinigung der fã $1 / 4$ hrenden Forscherinnen und Forscher des Landes. Sie wurde 1970 als Nachfolgeeinrichtung der Arbeitsgemeinschaft fã $1 / 4 \mathrm{r}$ Forschung des Landes Nordrhein-Westfalen gegrÃ $1 / 4$ ndet. Die Akademie ist in drei wissenschaftliche Klassen f $\tilde{A}^{1 / 4} / \mathrm{r}$ Geisteswissenschaften, fã $1 / 4$ r Naturwissenschaften und Medizin sowie fã $1 / 4$ r Ingenieurund Wirtschaftswissenschaften und in eine Klasse der KÃ $1 / 4$ nste gegliedert.

Mit Publikationen zu den wissenschaftlichen VortrÃagen in den Klassensitzungen, zu Ã ffentlichen Veranstaltungen und Symposien will die Akademie die Fach- und allgemeine Ãffentlichkeit Ã $1 / 4$ ber die Arbeiten der Akademie und ihrer Forschungsstellen informieren.

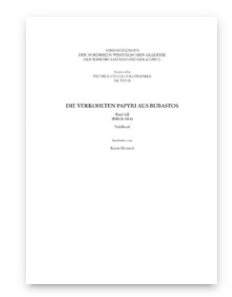

Pages: 72 Seiten, $68 \mathrm{~s} / \mathrm{w}$ Abb.

Language:

German

Subjects:

Ancient History, Classical Studies

Publisher: Brill | SchÃ ๆningh

\section{Series:}

Sonderreihe der

Abhandlungen

Papyrologica

Coloniensia,

Volume: 15/3, B

E-Book (PDF)

Released online:

29 Oct 2019

ISBN: 978-3-

657-78617-6

List price

Paperback

Publication date:

o7 Oct 2016

ISBN: 978-3-

5o6-78617-3

List price 
For more information see brill.com

Order information: Order online at brill.com +44330 333 0049 | customerservices@brill.com Submission information: brill.com/authors

Titles published by Brill | Fink, Brill | mentis or Brill | Schöningh: +49(o)715413279216| brill@brocom.de 